\title{
Analisis Potensi Perubahan Pemanfaatan Lahan Berdasarkan Model Spasial Harga Lahan di Kecamatan Tembelang Kabupaten Jombang
}

\author{
Muhammad Ermando Nurman Sasono dan Cahyono Susetyo \\ Departemen Perencanaan Wilayah dan Kota, Fakultas Teknik Sipil dan Perencanaan, Institut \\ Teknologi Sepuluh Nopember ITS \\ e-mail: cahyono_s@urplan.its.ac.id.
}

\begin{abstract}
Abstrak-Pembangunan interchange gerbang TOL Jombang di Kecamatan Tembelang menyebabkan harga lahan meningkat dan muncul indikasi perubahan pemanfaatan lahan. Untuk itu, pemerintah perlu mengantisipasi perubahan pemanfaatan lahan yang tidak sesuai dengan peruntukannya sebagaimana yang terdapat pada rencana tata ruang. Penentuan potensi perubahan pemanfaatan lahan dilakukan berdasarkan pada model spasial harga lahan yang secara keseluruhan meliputi tiga teknik analisis. (1) Teknik analisis Delphi bertujuan untuk mengidentifikasi faktor penentu harga lahan, (2) analisis regresi spasial digunakan untuk melakukan pemodelan spasial harga lahan, dan (3) analisis Query Builder menghasilkan peta potensi perubahan pemanfaatan lahan di Kecamatan Tembelang. Tiap tahapan penelitian menghasilkan luaran yang saling berkaitan. Terdapat 15 faktor penentu harga lahan yang telah konsensus dari teknik analisis Delphi dalam dua tahap iterasi. Adapun model spasial harga lahan dihasilkan dari model matematis memiliki konstanta 796.763,84565. Faktor yang berpengaruh positif dalam model tersebut yaitu jalur angkutan umum, daerah rawan banjir, fasilitas perdagangan dan jasa, jalan lingkungan, dan rencana jaringan jalan. Faktor yang berpengaruh negatif yakni fasilitas kesehatan, fasilitas pendidikan, fasilitas peribadatan, fasilitas perkantoran, jalan kolektor, kawasan permukiman, rencana kawasan industri, rencana kawasan permukiman, sungai, dan interchange gerbang TOL. Model spasial menunjukkan mayoritas harga lahan tinggi terdapat di sekitar interchange gerbang TOL dan semakin rendah di wilayah perbatasan Kecamatan Tembelang. Luas lahan di Kecamatan Tembelang menurut potensi perubahan pemanfaatannya dari lahan tidak terbangun ke lahan terbangun yang dibagi menjadi kategori tinggi, sedang, dan rendah secara berturut-turut yaitu 571,29 Ha (17\%), 788,68 Ha (23\%), dan 2.088,44 Ha (61\%).
\end{abstract}

Kata Kunci-interchange gerbang TOL Jombang, harga lahan, potensi perubahan pemanfaatan lahan.

\section{PENDAHULUAN}

$\mathrm{P}$ EMBANGUNAN infrastruktur merupakan wujud pemenuhan kebutuhan manusia, termasuk salah satunya adalah jaringan transportasi. Pembangunan infrastruktur pada suatu kawasan akan mempengaruhi pemanfaatan lahan pada kawasan di sekitarnya, sehingga hal ini menimbulkan perubahan atau konversi jenis penggunaan lahan. Perubahan bentuk pemanfaatan lahan akan berpotensi memberikan pengaruh pada bidang penggunaan lain yang ada di sekitarnya
[1]. Salah satu penyebab terjadinya perubahan suatu guna lahan yaitu perluasan jaringan infrastruktur terutama jaringan transportasi [2]. Terdapat hubungan keterkaitan antara perluasan jaringan infrastruktur khususnya jaringan transportasi terhadap harga lahan. Perluasan jaringan transportasi untuk memenuhi kebutuhan mobilitas manusia yang senantiasa bertambah menyebabkan harga lahan mengalami kecenderungan untuk naik secara alamiah [3].

Harga lahan pada dasarnya dipengaruhi oleh berbagai faktor. Harga lahan dan nilai lahan memiliki keterkaitan fungsional dalam pengertiannya, di mana harga lahan umumnya ditentukan oleh nilai lahan atau harga lahan akan mencerminkan tinggi rendahnya nilai lahan [4]. Faktor lokasi mempengaruhi nilai tanah. Menurut penelitian tersebut, nilai tanah dipengaruhi oleh variabel-variabel seperti, jarak ke pusat kota, lebar jalan, jarak ke perguruan tinggi, dan kondisi jalan aspal atau tidak. Suatu kawasan yang memiliki kelengkapan infrastruktur baik cenderung memiliki harga lahan yang tinggi, sehingga dengan kondisi infrastruktur yang lengkap, masyarakat cenderung untuk mendirikan bangunan pada lokasi tersebut meskipun dengan harga yang relatif tinggi. Oleh karena itu, harga lahan sebagai pertimbangan dalam mendirikan bangunan dapat digunakan sebagai pendekatan dalam mengetahui potensi perubahan pemanfaaatan lahan di suatu kawasan.

Di Kabupaten Jombang, saat ini sedang dibangun ruas jalan TOL yang menghubungkan wilayah Mojokerto dan Kertosono yang panjangnya mencapai 40,5 km [5]. Pembangunan pintu TOL berdampak pada kenaikan harga lahan di wilayah sekitarnya, dimana harga lahan tertinggi terdapat pada jenis penggunaan lahan perdagangan dan jasa serta permukiman [6]. Rahadyan dalam penelitiannya telah melakukan wawancara dengan Kepala Bidang Permukiman, Dinas Cipta Karya dan Tata Ruang Kabupaten Jombang pada tanggal 7 November 2014, bahwa terbangunnya interchange TOL di Kecamatan Bandarkedungmulyo Kabupaten Jombang telah memicu perubahan harga lahan di sekitar kawasan [7]. Setyagama juga meneliti kawasan interchange gerbang TOL Jombang di Kecamatan Tembelang dan mengidentifikasi adanya peningkatan harga lahan sebanyak tiga kali lipat karena pembangunan interchange tersebut [8].

Pemerintah Kabupaten Jombang perlu mengidentifikasi lahan yang berpotensi berubah pemanfaaatannya dikarenakan 
adanya pembangunan interchange gerbang TOL Jombang di Kecamatan Tembelang. Arahan Rencana Tata Ruang Wilayah Kabupaten Jombang Tahun 2009-2029 menetapkan kawasan interchange gerbang TOL Jombang pada Kecamatan Tembelang sebagai Kawasan Strategis Cepat Tumbuh, sehingga mengakibatkan perkembangan wilayah pada kawasan tersebut menjadi relatif cepat. Perkembangan wilayah tersebut dapat menjadi ancaman bagi ketersediaan lahan pertanian khususnya LP2B (Lahan Pertanian Pangan Berkelanjutan), mengingat harga lahan yang akan meningkat, sehingga lahan tersebut cenderung dialihfungsikan sebagai lahan non pertanian. Hasil penelitian Rusastra dalam Ilham pada tahun 1995, alasan utama petani melakukan konversi lahan adalah karena kebutuhan dan harga lahan yang tinggi, skala usaha yang kurang efisien untuk diusahakan [9]. Identifikasi harga lahan dapat dilakukan dengan pemodelan spasial, selain menghasilkan informasi harga lahan, juga dapat digunakan dalam menganalisis potensi perubahan pemanfaatan lahannya. Penelitian ini bertujuan untuk menganalisis potensi perubahan pemanfatan lahan berdasarkan model spasial harga lahan pasca pembangunan interchange gerbang TOL di Kecamatan Tembelang, Kabupaten Jombang. Penelitian ini bukan mengarahkan pembangunan pada lahan-lahan yang harga lahannya tinggi dan berpotensi berubah pemanfaatannya, melainkan sebagai acuan untuk mengantisipasi perubahan pemanfaatan lahan yang meliputi lahan pertanian maupun non pertanian, yang tidak sesuai dengan rencana tata ruang yang berlaku.

\section{METODE PENELITIAN}

\section{A. Jenis dan Pendekatan Penelitian}

Penelitian ini menggunakan pendekatan kuantitatif. Hal ini dikarenakan metode analisis yang digunakan secara mayoritas berkaitan dengan pengolahan data numerik. Jenis penelitian ini berdasarkan pendekatan kuantitatif menurut Mc Millan dan Schumacher terbagi menjadi tiga, yaitu penelitian dengan metode deskriptif, korelasional, dan Ex Post Facto [10].

\section{B. Aspek dan Faktor Penelitian}

Terdapat empat aspek dan dua belas faktor yang digunakan dalam penelitian ini. Faktor-faktor tersebut sifatnya spasial yang direpresentasikan dengan jarak terhadap lahan dalam satuan meter. Aspek sarana pelayanan umum (SPU) terdiri dari faktor fasilitas peribadatan, fasilitas pendidikan, fasilitas kesehatan, fasilitas perkantoran, fasilitas perdagangan dan jasa. Aspek jaringan transportasi terdiri dari faktor interchange gerbang TOL, jalan kolektor, jalan lingkungan. Aspek lingkungan perumahan terdiri dari kawasan permukiman dan daerah rawan banjir. Aspek kebijakan pemerintah terdiri dari faktor rencana kawasan industri dan rencana jaringan jalan.

\section{Populasi dan Sampel}

Pengambilan sampel dibutuhkan untuk mendapatkan data harga lahan dari seluruh jumlah kepala keluarga (KK) di Kecamatan Tembelang sebagai populasinya. Pengambilan sampel disesuaikan dengan jumlah KK di Kecamatan Tembelang pada setiap desa yang totalnya mencapai 13.408 dengan total 388 sampel yang didapat dari perhitungan menggunakan rumus Slovin. Jumlah sampel tersebut dapat bertambah jika responden memiliki lahan non terbangun lainnya. Data harga lahan didapatkan dengan metode wawancara kuisioner terhadap sampel-sampel tesebut.

\section{Metode Analisis}

1) Mengidentifikasi faktor-faktor yang mempengaruhi harga lahan di Kecamatan Tembelang, Kabupaten Jombang.

Teknik analisis yang digunakan untuk mengidentifikasi faktor spasial penentu harga lahan adalah analisis Delphi. Teknik analisis Delphi merupakan pengolahan data secara kualitatif yang diperoleh melalui kuesioner dan wawancara kepada stakeholders terpilih dan mempunyai tingkat validasi tinggi karena disampaikan oleh para pakar serta melalui iterasi. Proses tanya jawab berakhir apabila kesepakatan antara para stakeholders telah tercapai setelah informasi yang lengkap terkumpul [11].

2) Merumuskan model spasial harga lahan di Kecamatan Tembelang, Kabupaten Jombang.

Harga lahan di Kecamatan Tembelang dianalisis menggunakan teknik analisis regresi spasial. Langkah pertama adalah menganalisis jarak euklides faktor spasial menggunakan Euclidean Distance pada software ESRI ArcGIS 10.1. Kemudian harga lahan dan jarak terhadap faktorfaktor yang mempengaruhinya dianalisis menggunakan Ordinary Least Squares (OLS). Model matematis yang dihasilkan lalu dianalisis dengan Raster Calculator sehingga membentuk model spasial harga lahan di Kecamatan Tembelang. Rumus perhitungan OLS adalah sebagai berikut.

$$
Y=\beta_{0}+\beta_{1} \chi_{1}+\beta_{2} \chi_{2}+\ldots
$$

Keterangan :

$$
\begin{array}{ll}
\mathrm{Y} & =\text { variabel terikat } / \mathrm{dependen} \\
\beta_{0} & =\text { konstanta }(\text { intercept }) \\
\beta_{1}, \beta_{2}, \text { dst. } & =\text { koefisien regresi spasial (slope) } \\
\chi_{1}, \chi_{2}, \text { dst. } & =\text { variabel penjelas/independen }
\end{array}
$$

3) Menganalisis potensi perubahan pemanfaatan lahan di Kecamatan Tembelang, Kabupaten Jombang.

Untuk memudahkan identifikasi harga lahan, dilakukan pengelompokan atau klasifikasi harga lahan secara kuantitatif maupun kualitatif. Metode pengelompokan harga lahan dilakukan dengan mencari nilai kuartil I $\left(\mathrm{Q}_{1}\right)$ dan III $\left(\mathrm{Q}_{3}\right)$ pada data tunggal harga lahan pasar hasil survei untuk menghasilkan tiga kelas harga lahan. Novananda dan Setiawan juga menggunakan kalkulasi kuartil untuk mengklasifikasikan jumlah produksi emisi karbon dioksida pada analisis persebaran spasial produksi gas tersebut dari penggunaan lahan permukiman di Kawasan Perkotaan Gresik [12].

$$
Q_{i}=\frac{i(n+1)}{4}
$$

Keterangan :

$Q_{i}=$ Kuartil ke-i

$n$ = Jumlah data 
Untuk mengetahui potensi perubahan pemanfaatan lahan seara spasial, dilakukan Analisis Query Builder. Analisis Query Builder merupakan analisis pelacakan data sebagai fasilitas yang digunakan untuk melacak feature-feature berdasarkan data atributnya. Query Builder juga dapat digunakan untuk mengetahui feature-feature mana saja yang sesuai dengan kriteria yang telah ditentukan [13]. Sebelumnya, data spasial harga lahan dan penggunaan lahan eksisting Kecamatan Tembelang digabungkan dengan Overlay Intersect. Query Builder memanfaatkan dua tools yakni Select By Attributes dan Field Calculator. Select By Attributes berfungsi untuk menyeleksi data, sedangkan Field Calculator digunakan untuk memasukkan data dan menyusun data baru menggunakan Structured Query Language (SQL).

\section{HASIL DAN DISKUSI}

A. Mengidentifikasi faktor-faktor yang mempengaruhi harga lahan di Kecamatan Tembelang, Kabupaten Jombang.

Keseluruhan proses analisis Delphi telah melalui 2 kali iterasi dengan 3 kali wawancara eksplorasi. Berdasarkan hasil wawancara tersebut ditemukan beberapa faktor yang tidak consensus sehingga perlu dilakukan iterasi. Eksplorasi terhadap faktor menghasilkan beberapa faktor baru yang diajukan dari stakeholders.

Keterangan :

$$
\begin{array}{ll}
\mathrm{R} & =\text { Responden } \\
\mathrm{P} & =\text { Penting } \\
\mathrm{TP} & =\text { Tidak penting } \\
* & =\text { Belum konsensus }
\end{array}
$$

Berdasarkan hasil analisis Delphi pada faktor-faktor hasil kajian pustaka, didapatkan 15 faktor yang berpengaruh terhadap harga lahan di Kecamatan Tembelang, Kabupaten Jombang. Tiga faktor baru hasil wawancara eksplorasi yaitu jalur angkutan umum, sungai, dan rencana kawasan permukiman.

Tabel 1.

Rekapitulasi Jawaban Kuisioner Delphi Tahap I

\begin{tabular}{lllllll}
\hline \multicolumn{1}{c}{ Aspek } & \multicolumn{1}{c}{ Faktor } & R1 & R2 & R3 & R4 & R5 \\
\hline Sarana & Fasilitas peribadatan & P & P & P & P & P \\
pelayanan & Fasilitas pendidikan & P & P & P & P & P \\
umum & Fasilitas kesehatan & P & P & P & P & P \\
& Fasilitas perkantoran & $\mathrm{P}$ & $\mathrm{P}$ & $\mathrm{P}$ & $\mathrm{P}$ & $\mathrm{P}$ \\
& Fasilitas perdagangan & $\mathrm{P}$ & $\mathrm{P}$ & $\mathrm{P}$ & $\mathrm{P}$ & $\mathrm{P}$ \\
& dan jasa & & & & & \\
Jaringan & Interchange gerbang & $\mathrm{P}$ & $\mathrm{P}$ & $\mathrm{P}$ & $\mathrm{P}$ & $\mathrm{P}$ \\
transportasi & TOL & & & & & \\
& Jalan kolektor & $\mathrm{P}$ & $\mathrm{P}$ & $\mathrm{P}$ & $\mathrm{P}$ & $\mathrm{P}$ \\
& Jalan lingkungan* & $\mathrm{P}$ & $\mathrm{P}$ & $\mathrm{TP}$ & $\mathrm{TP}$ & $\mathrm{P}$ \\
Lingkungan & Kawasan permukiman & $\mathrm{P}$ & $\mathrm{P}$ & $\mathrm{P}$ & $\mathrm{P}$ & $\mathrm{P}$ \\
permukiman & Daerah rawan banjir & $\mathrm{P}$ & $\mathrm{P}$ & $\mathrm{P}$ & $\mathrm{P}$ & $\mathrm{P}$ \\
Kebijakan & Rencana kawasan & $\mathrm{P}$ & $\mathrm{P}$ & $\mathrm{P}$ & $\mathrm{P}$ & $\mathrm{P}$ \\
pemerintah & industri & & & & & \\
& Rencana jaringan jalan & $\mathrm{P}$ & $\mathrm{P}$ & $\mathrm{P}$ & $\mathrm{P}$ & $\mathrm{P}$ \\
\hline \hline
\end{tabular}

B. Merumuskan model spasial harga lahan di Kecamatan Tembelang, Kabupaten Jombang.

Dari hasil OLS, terdapat 9 faktor signifikan dan 6 faktor tidak signifikan (signifikansi $\mathrm{P}<0.05$ ). $R$-Squared yang dihasilkan adalah 53,58\% dengan Adjusted $R$-Squared $51,78 \%$. Berikut model matematis yang dihasilkan.

$Y=796.763,84565+2.487,105957 \chi_{1}+56,631707 \chi_{2}-$

$$
\begin{aligned}
& 14,169566 \quad \chi_{3}-87,7424 \quad \chi_{4}-23,881509 \chi_{5}+ \\
& 435,957510 \chi_{6}-27,895809 \chi_{7}-2.899,296218 \chi_{8}+ \\
& 851,225198 \chi_{9}-376,107305 \chi_{10}-24,082298 \chi_{11}+ \\
& 6,513593 \chi_{12}-859,315923 \chi_{13}-299,638954 \chi_{14}- \\
& 126,278851 \chi_{15}
\end{aligned}
$$

Keterangan :

$\mathrm{Y}$ = harga lahan (rupiah per meter persegi)

$\mathrm{X}_{1}=$ jalur angkutan umum (meter)

$\mathrm{X}_{2}=$ daerah rawan banjir (meter)

$\mathrm{X}_{3}=$ fasilitas kesehatan (meter)

$\mathrm{X}_{4}=$ fasilitas pendidikan (meter)

$\mathrm{X}_{5}=$ fasilitas peribadatan (meter)

$\mathrm{X}_{6}=$ fasilitas perdagangan dan jasa (meter)

$\mathrm{X}_{7}=$ fasilitas perkantoran (meter)

$\mathrm{X}_{8}=$ jalan kolektor (meter)

$\mathrm{X}_{9}=$ jalan lingkungan (meter)

$\mathrm{X}_{10}=$ kawasan permukiman (meter)

$\mathrm{X}_{11}=$ rencana kawasan industri (meter)

$\mathrm{X}_{12}=$ rencana jaringan jalan (meter)

\begin{tabular}{|c|c|c|c|c|c|c|}
\hline Aspek & Faktor & $\mathrm{R} 1$ & $\mathrm{R} 2$ & R3 & $\mathrm{R} 4$ & R5 \\
\hline Aksesibilitas & Jalur angkutan umum & $\mathrm{P}$ & $\mathrm{P}$ & $\mathrm{P}$ & $\mathrm{P}$ & $\mathrm{P}$ \\
\hline $\begin{array}{l}\text { Lingkungan } \\
\text { permukiman }\end{array}$ & Sungai & $\mathrm{P}$ & $\mathrm{P}$ & $\mathrm{P}$ & $\mathrm{P}$ & $\mathrm{P}$ \\
\hline
\end{tabular}

$\mathrm{X}_{13}=$ rencana kawasan permukiman (meter)

$\mathrm{X}_{14}=$ sungai (meter)

$\mathrm{X}_{15}=$ interchange gerbang TOL (meter)

Tabel 2.

Rekapitulasi Jawaban Kuisioner Delphi Tahap II

\begin{tabular}{llccccc}
\hline \hline \multirow{2}{*}{ Aspek } & \multicolumn{1}{c}{ Faktor } & R1 & R2 & R3 & R4 & R5 \\
\hline Aksesibilitas & Jalan lingkungan & $\mathrm{P}$ & $\mathrm{P}$ & $\mathrm{P}$ & $\mathrm{P}$ & $\mathrm{P}$ \\
& Jalur angkutan umum* & $\mathrm{P}$ & $\mathrm{TP}$ & $\mathrm{P}$ & $\mathrm{P}$ & $\mathrm{P}$ \\
& Sungai* & $\mathrm{TP}$ & $\mathrm{P}$ & $\mathrm{P}$ & $\mathrm{P}$ & $\mathrm{P}$ \\
Kebijakan & Rencana kawasan & $\mathrm{P}$ & $\mathrm{P}$ & $\mathrm{P}$ & $\mathrm{P}$ & $\mathrm{P}$ \\
pemerintah & permukiman & & & & & \\
\hline \hline
\end{tabular}

Tabel 3.

Rekapitulasi Jawaban Kuisioner Delphi Tahap III 


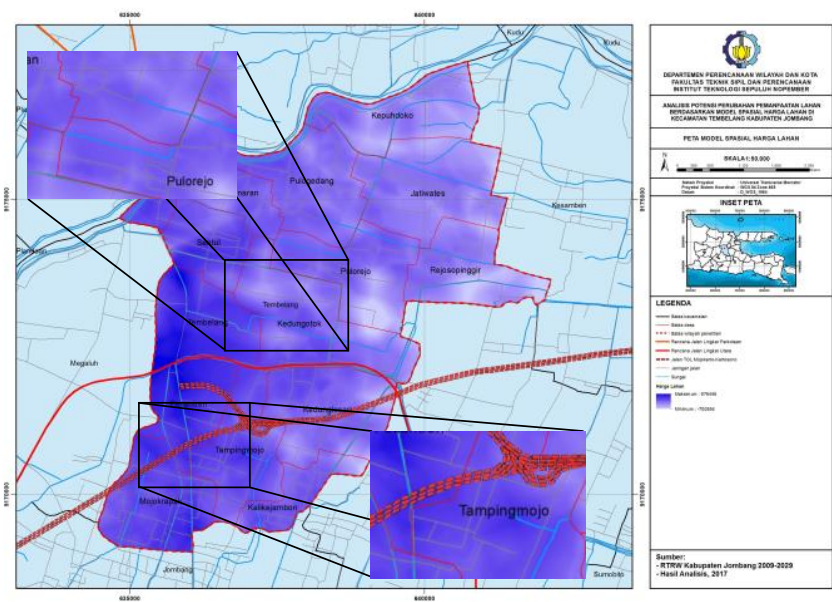

Gambar 1. Peta model spasial harga lahan.

C. Menganalisis potensi perubahan pemanfaatan lahan di Kecamatan Tembelang, Kabupaten Jombang.

Penentuan kelas harga lahan dibutuhkan untuk mengidentifikasi potensi perubahan pemanfaatan lahan. Batas kelas harga lahan didapatkan dari angka kuartil I dan kuartil III. Dengan menggunakan software Microsoft Excel 2013 diperoleh angka kuartil I dan kuartil III secara berturut-turut yaitu 200.000 dan 410.000. Dengan demikian terdapat tiga kelas harga lahan yaitu 0 - 200.000,000 rupiah $/ \mathrm{m}^{2}$ (Kelas I), $200.000,001$ - 410.000,000 rupiah $/ \mathrm{m}^{2}$ (Kelas II), dan 410.000,001 - 976.456,375 rupiah $/ \mathrm{m}^{2}$ (Kelas III), dan selanjutnya dilakukan Reclassify pada ESRI ArcGGIS 10.1 untuk menampilkan data spasial harga lahan menurut kelasnya.

Konversi data dari raster ke vektor dalam bentuk shapefile dibutuhkan untuk tahapan berikutnya, yaitu penyusunan data baru. Konversi data spasial menggunakan Conversion Tools di dalam sub menu From Raster kemudian pada bagian Raster to Polygon. Berdasarkan hasil perhitungan luasan menggunakan Calculate Geometry, diketahui bahwa harga lahan kelas I (0 $200.000,000 \mathrm{rupiah} / \mathrm{m}^{2}$ ) mendominasi wilayah Kecamatan Tembelang dengan luas mencapai 1.475,54 Ha. Presentase luasan harga lahan dari kelas I hingga III secara berturut-turut yaitu $43 \%, 30 \%$, dan $27 \%$. Luasan harga lahan kelas II yakni 1.046,39 Ha, sedangkan kelas III yaitu 926,51 Ha.

Penyusunan data merupakan tahap akhir dalam analisis potensi perubahan pemanfaatan lahan. Output akhir dari tahap ini yatu peta potensi perubahan pemanfaatan lahan. Langkah pertama yaitu melakukan tumpang tindih data spasial harga lahan dan penggunaan lahan eksisting Kecamatan Tembelang menggunakan Overlay Intersect pada ESRI ArcGIS 10.1. Kemudian menyediakan kolom (field) potensi perubahan pemanfaatan lahan pada Attribute Table yang dimiliki file baru hasil Overlay Intersect. Potensi perubahan pemanfaatan lahanyang menjadi fokus dalam penelitian ini hanya pada lahan tidak terbangun menjadi lahan terbangun, karena potensi perubahan pemanfaatan lahan terbangun menjadi lahan tidak terbangun cenderung rendah atau kecil kemungkinannya.

Potensi perubahan pemanfaatan lahan tertinggi yaitu pada jenis penggunaan lahan sawah. Sebesar 571,29 Ha luas lahan tidak terbangun berpotensi tinggi untuk dikonversi menjadi lahan terbangun berupa permukiman. Jenis penggunaan lahan permukiman memiliki potensi perubahan pemanfaatan yang rendah, karena kemungkinan lahan terbangun berubah menjadi lahan tidak terbangun dapat dikatakan sangat kecil. Potensi perubahan pemanfaatan lahan pada jenis penggunaan lahan

Tabel 4.

Harga Lahan dan Potensi Perubahan Pemanfaatannya

\begin{tabular}{|c|c|c|c|}
\hline Kelas & Harga Lahan $\left(\mathrm{Rp} / \mathrm{m}^{2}\right)$ & Potensi & Keterangan \\
\hline I & $0-200.000,000$ & Rendah & $\begin{array}{l}\text { Kemungkinan } \\
\text { lahan dikonversi } \\
\text { sangat besar, } \\
\text { penggunaan lahan } \\
\text { berpotensi untuk } \\
\text { menyesuaikan } \\
\text { nilai ekonomis } \\
\text { harga lahannya. }\end{array}$ \\
\hline II & $200.000,001-410.000,000$ & Sedang & $\begin{array}{l}\text { Kemungkinan } \\
\text { lahan seimbang } \\
\text { antara dikonversi } \\
\text { atau tidak. }\end{array}$ \\
\hline III & $410.000,001-976.456,375$ & Tinggi & $\begin{array}{l}\text { Kemungkinan } \\
\text { lahan dikonversi } \\
\text { sangat kecil, } \\
\text { penggunaan lahan } \\
\text { dengan harga } \\
\text { lahannya saat ini } \\
\text { cenderung tetap. }\end{array}$ \\
\hline
\end{tabular}

Tabel 5.

Luas Pemanfaatan Lahan dan Potensi Perubahannya

\begin{tabular}{lrrr}
\hline \hline $\begin{array}{c}\text { Jenis Pemanfaatan } \\
\text { Lahan }\end{array}$ & \multicolumn{1}{c}{$\begin{array}{c}\text { Potensi } \\
\text { Tinggi }\end{array}$} & \multicolumn{1}{c}{$\begin{array}{l}\text { Potensi } \\
\text { Sedang }\end{array}$} & \multicolumn{1}{c}{$\begin{array}{c}\text { Potensi } \\
\text { Rendah }\end{array}$} \\
\hline Sawah & 481,67 & 428,07 & 1004,65 \\
Kebun & 35,73 & 122,1 & 139,64 \\
Semak belukar & 4,83 & 35,93 & 36,65 \\
Tanah ladang & 49,06 & 202,58 & 196,30 \\
Permukiman & 0,0 & 0,0 & 711,2 \\
Total & 571,29 & 788,68 & 2088,44 \\
\hline \hline
\end{tabular}

tidak terbangun (sawah, kebun, semak belukar, dan tanah ladang) perlu diantisipasi sehingga pelanggaran tata ruang yang terjadi di kemudian hari dapat dicegah dan ditangani dengan segera. Hasil analisis potensi perubahan pemanfaatan lahan tidak dapat diaplikasikan pada lahan yang telah ditetapkan pemanfaatannya menurut peraturan dan kebijakan yang berlaku. Hal ini dikarenakan lahan tersebut memiliki fungsi tertentu yang tidak dapat dikonversikan dalam keadaan apapun, sehingga potensi perubahan pemanfaatannya sama dengan nol. Contoh dari lahan tersebut antara lain yaitu Lahan Pertanian Pangan Berkelanjutan (LP2B) dan zona sempadan (sungai, jalan, rel kereta api, pantai, dsb.). 


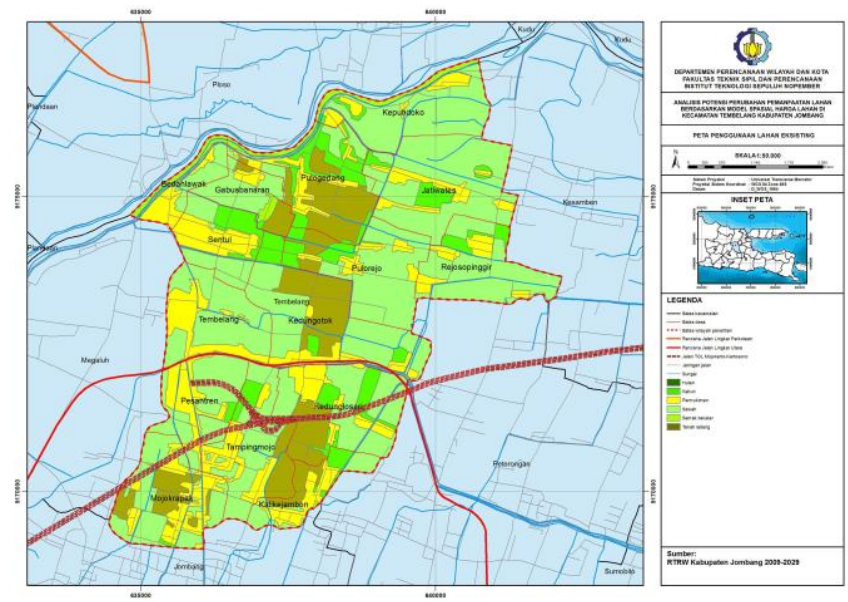

Gambar 2. Peta penggunaan lahan eksisting.

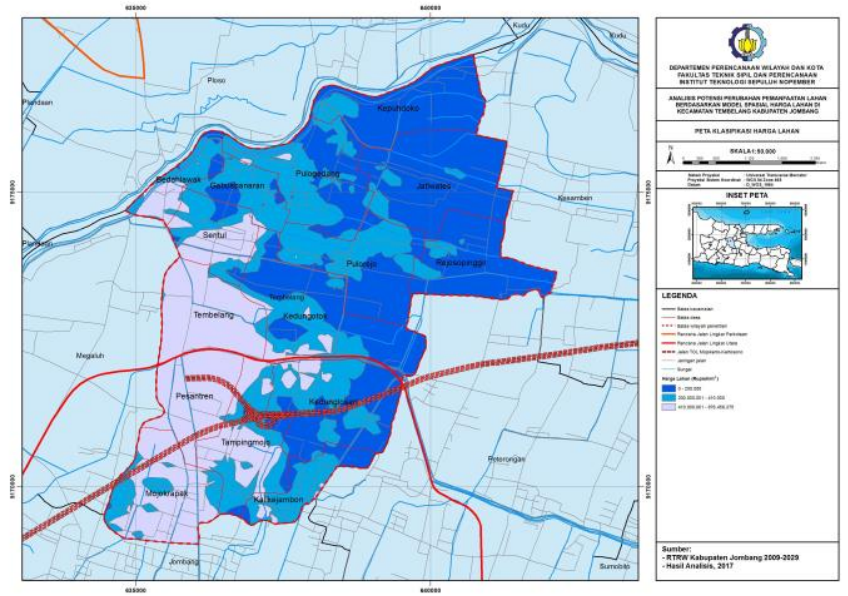

Gambar 3. Peta klasifikasi harga lahan.

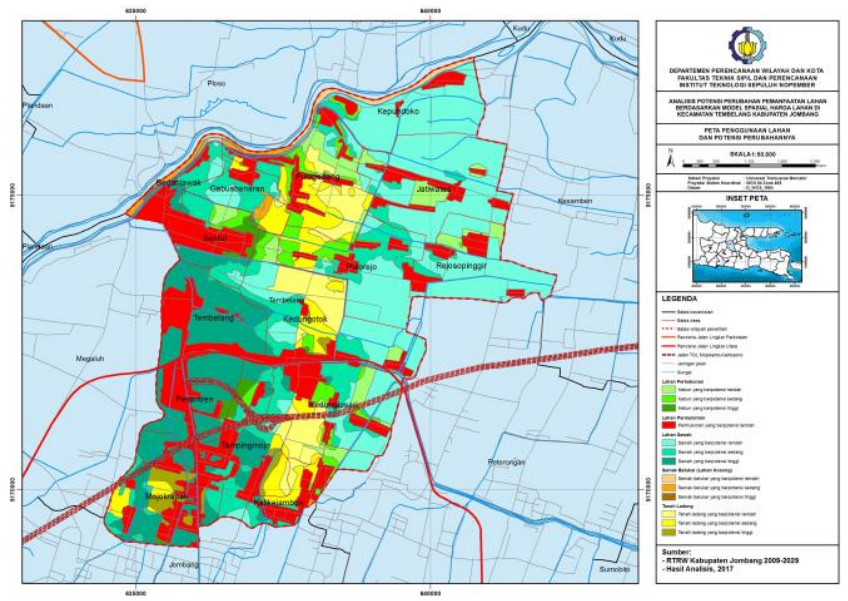

Gambar 4. Peta pemanfaatan lahan dan potensi perubahannya.

\section{KESIMPULAN}

Terdapat beberapa poin kesimpulan yang dihasilkan. Kesimpulan tersebut merupakan output dari tiap analisis dalam menjawab sasaran penelitian. Berikut adalah kesimpulan dari penelitian ini.

1) Terdapat 15 faktor yang menentukan harga lahan di Kecamatan Tembelang, Kabupaten Jombang. Faktorfaktor itu dibagi menurut aspeknya. Aspek Sarana Pelayanan Umum (SPU) terdiri dari faktor fasilitas peribadatan, faktor fasilitas pendidikan, faktor fasilitas kesehatan, faktor fasilitas perkantoran, dan faktor fasilitas perdagangan dan jasa. Aspek jaringan transportasi terdiri dari faktor interchange gerbang TOL, jalan kolektor, jalan lingkungan, dan jalur angkutan umum. Aspek lingkungan permukiman terdiri dari faktor daerah rawan banjir, faktor kawasan permukiman, dan faktor sungai. Aspek kebijakan pemerintah terdiri dari faktor rencana kawasan industri, faktor rencana jaringan jalan, faktor rencana kawasan permukiman.

2) Model matematis yang dihasilkan berbentuk persamaan $\mathrm{Y}=796.763,84565+2.487,105957 \mathrm{X}_{1}+56,631707 \mathrm{X}_{2}-$ $14,169566 X_{3}-87,7424 X_{4}-23,881509 X_{5}+435,957510$ $X_{6}-27,895809 X_{7}-2.899,296218 X_{8}+851,225198 X_{9}-$ $376,107305 X_{10}-24,082298 X_{11}+6,513593 X_{12}-$ $859,315923 X_{13}-299,638954 X_{14}-126,278851 X_{15}$. Y merupakan harga lahan dan $X$ adalah faktor-faktor yang mempengaruhinya, dimana $\mathrm{X}_{1}$ adalah jalur angkutan umum, $\mathrm{X}_{2}$ adalah daerah rawan banjir, $\mathrm{X}_{3}$ adalah fasilitas kesehatan, $\mathrm{X}_{4}$ adalah fasilitas pendidikan, $\mathrm{X}_{5}$ adalah fasilitas peribadatan (meter), $\mathrm{X}_{6}$ adalah fasilitas perdagangan dan jasa, $\mathrm{X}_{7}$ adalah fasilitas perkantoran, $\mathrm{X}_{8}$ adalah jalan kolektor, $\mathrm{X}_{9}$ adalah jalan lingkungan, $\mathrm{X}_{10}$ adalah kawasan permukiman, $X_{11}$ adalah rencana kawasan industri, $\mathrm{X}_{12}$ adalah rencana jaringan jalan, $\mathrm{X}_{13}$ adalah rencana kawasan permukiman, $\mathrm{X}_{14}$ adalah sungai, dan $\mathrm{X}_{15}$ adalah interchange gerbang TOL (meter). Model spasial menunjukkan bahwa harga lahan yang tinggi cenderung berada di dekat interchange gerbang TOL.

3) Harga lahan diklasifikasikan dengan perhitungan kuartil data menjadi tiga kelas yaitu $0-200.000,000 \mathrm{rupiah} / \mathrm{m}^{2}$ (kelas I), 200.000,001 - 410.000,000 rupiah/m $/ \mathrm{m}^{2}$ (kelas II), $410.000,001$ - 976.456,375 rupiah/ $\mathrm{m}^{2}$ (kelas III). Selanjutnya data spasial harga lahan dan penggunaan lahan digabungkan dengan teknik Overlay Intersect dan dilakukan seleksi data. Luas lahan yang berpotensi tinggi, sedang, dan rendah untuk berubah pemanfaatannya secara berturut-turut yaitu $571,29 \mathrm{Ha}$ (17\%); 788,68 Ha (23\%); dan 2088,44 Ha (61\%).

Analisis potensi perubahan pemanfaatan lahan dapat digunakan selama harga lahan tetap atau berubah namun tidak signifikan. Hasil penelitian ini dapat dijadikan sebagai referensi dan masukan terhadap dokumen rencana, informasi zona nilai tanah, dan penentuan NJOP tanah. Di samping itu, hasil penelitian ini dapat digunakan untuk mengendalikan alih fungsi lahan yang tidak sesuai dengan peruntukkannya. Ke depannya penelitian ini dapat dikembangkan dengan melibatkan sampel yang lebih proporsional dan akurat, faktorfaktor determinan harga lahan lainnya, serta menerapkan simulasi prediksi penggunaan lahan berdasarkan potensi perubahannya. Metode klasifikasi harga lahan perlu meninjau data spasial penggunaan lahan pada tahun-tahun sebelumnya untuk dapat diketahui rentang harga lahan dimana terjadi konversi lahan tidak terbangun ke lahan terbangun. 


\section{DAFTAR PUSTAKA}

[1] H. . Yunus, Struktur Tata Ruang Kota. Yogyakarta: Pustaka Pelajar, 2000.

[2] S. V. Prawiro, "Kemungkinan Perbahan Guna Lahan Akibat Pembangunan Jalan Layang Non-Tol Antasari Blok M Berdasarkan Persepsi Masyarakat," J. Perenc. Wil. dan Kota A SAPPK, 2014.

[3] G. Mangkoesoebroto, "Pengaruh Pajak Atas Harga Tanah," $J$. Ekon. dan Bisnis Indones., vol. 7, 1992.

[4] W. Hendrawan, "Pola Spasial dan Faktor-faktor yang Mempengaruhi Perubahan Harga Lahan Kawasan Pusat Kota Madiun. Studi," Institut Teknologi Sepuluh Nopember, 2010.

[5] Y. Wibisono, "Tancap Gas, Tol Seksi 2 Ditarget Selesai 2017," 2016. [Online]. Available: http://beritajatim.com/ekonomi/ 276018/tancap_gas,_tol_seksi_2_ditarget_selesai_2017.

[6] D. K. Masykuroh and I. Rudiarto, Kajian Perubahan Penggunaan Lahan dan Harga Lahan di Wilayah Sekitar Pintu TOL Ungaran. TATALOKA, 2016.

[7] G. . Rahadyan, "Skenario Pengembangan Lahan Permukiman Pasca Terbangunnya Interchange Jalan TOL Mojokerto-Kertosono di Kawasan Perkotaan Bandar Kedungmulyo Kabupaten Jombang," Institut Teknologi Sepuluh Nopember, 2015.

[8] A. . Setyagama and A. . Navastara, "Zonasi Kawasan Terdampak Akibat Pembangunan Interchange TOL di Kabupaten Jombang," $J$. Tek. ITS, pp. C207-C211, 2014

[9] Y. Ilham, N., Syaukat and S. Friyatno, "Perkembangan dan Faktorfaktor yang Mempengaruhi Konversi Lahan Sawah serta Dampak Ekonominya," SOCA (Socio-Economic Agric. Agribusiness), 2004.

[10] J. H. McMillan and S. Schumacher, Research in Education. New York. New York: Longman Scientific \& Technical, 2003.

[11] Sudjana, Metode Statistik. Bandung: Tarsito, 2000.

[12] E. Novananda and R. P. Setiawan, "Persebaran Spasial Produksi Emisi Karbon Dioksida (CO2) dari Penggunaan Lahan Permukiman di Kawasan Perkotaan Gresik Bagian Timur," J. Tek. ITS, vol. 4, pp. C11-C16, 2015.

[13] F. W. Indonesia, Modul Pelatihan Sistem Informasi Geografis. Bogor: FWI, 2010. 